\title{
Chlamydial genital infection in prostitutes in Iran
}

\author{
S DAROUGAR, * B ARAMESH, † J A GIBSON, \& J D TREHARNE, * AND B R JONES* \\ From the *Subdepartment of Virology, Institute of Ophthalmology, London; the + School of Public Health, \\ Teheran, Iran; and the $¥$ Department of Microbiology, Cardiothoracic Institute, London
}

SUMMARY The prevalence of chlamydial genital infection was studied in 177 prostitutes in Iran; 100 in Teheran and 77 in the port of Bandar Abbas. Chlamydia trachomatis was isolated in eight $(6 \cdot 9 \%)$ of 116 patients with valid cultures. Type-specific antibodies were found against $C$ trachomatis serotypes D to K (genital serotypes) in $94 \cdot 2 \%$ and against serotypes A to C (trachoma serotypes) in $2 \%$ of the prostitutes. Type-specific IgM at a titre of $\geqslant 8$, indicating current infection, was found in $29 \cdot 2 \%$, whereas type-specific $\operatorname{IgG}$ at a titre $\geqslant 64$, suggesting a current or recent infection, was present in $71 \cdot 5 \%$.

The lower chlamydial isolation rate in these women may have been due to previous treatment with antichlamydial drugs and because of immune responses resulting from repeated reinfection with chlamydiae. The results indicate that in Iran prostitutes are commonly infected with $C$ trachomatis and are probably a major reservoir of chlamydial genital infection.

\section{Introduction}

We have reported that urethral infection, caused by Chlamydia trachomatis serotypes $\mathrm{D}$ to $\mathrm{K}$, occurs among the urban population of Iran. ${ }^{1}$ Those results indicated that prostitutes may have been a major source of chlamydial genital infection.

We present the results of an investigation of the prevalence of chlamydial genital infection in prostitutes in Iran.

\section{Patients and methods}

One hundred and seventy-seven women who attended consecutively special clinics for registered prostitutes either in Teheran or Bandar Abbas (a port in Southern Iran) for their regular weekly examination for sexually transmitted diseases were included in the study.

Specimens for chlamydial isolation were taken from the cervical canal on cottonwool swabs. These were stored in 2SP transport medium with antibiotics ${ }^{2}$ and $3 \%(\mathrm{v} / \mathrm{v})$ fetal calf serum. Transport of specimens to London and methods of culture in irradiated McCoy cells have been described. ${ }^{13}$

Blood was taken by venepuncture. Sera were separated and stored at $-20^{\circ} \mathrm{C}$. Transport of sera to

\footnotetext{
Address for reprints: Professor S Darougar, Subdepartment of Virology, Institute of Ophthalmology, Judd Street, London WC1H 9QS
}

Accepted for publication 18 August 1982
London and methods for detecting type-specific antichlamydial IgG and IgM using a modified microimmunofluorescence (micro-IF) test are described. ${ }^{14}$

Isolates were serotyped using a micro-IF test. 5

\section{Results}

Of the 177 female prostitutes studied, 100 were from Teheran and 77 from Bandar Abbas. Their ages ranged from 15 to 55 years with a mean of 29 years. Each woman had had several episodes of genital infection and had been treated frequently either in the clinic or by self-medication, usually with drugs active against chlamydiae (that is, tetracyclines, erythromycin, and sulphonamides). During specimen collection a discharge was visible in the cervical canal of all women; in $140(79 \cdot 1 \%)$ this was profuse.

Culture for C trachomatis was invalid in $61(34 \cdot 5 \%)$ women because of gross bacterial and fungal contamination or poor cell monolayers. C trachomatis was isolated in eight $(6.9 \%)$ of the other 116 women.

Type-specific serum antibodies against $C$ trachomatis serotypes D to $K$ were found in $145(94 \cdot 2 \%)$ women and against serotypes $A$ to $C$ in three $(2 \cdot 1 \%)$ of the 154 patients tested. Type-specific IgM against serotypes $\mathrm{D}$ to $\mathrm{K}$ at a titre of $\geqslant 8$ indicating current infection with these serotypes was found in $45(29 \cdot 2 \%)$ women (table). Type-specific IgG against serotypes D to $K$ at a titre of $\geqslant 64$ indicating current or recent infection ${ }^{6}$ was found in $110(71 \%)$ women (table). IgG against serotypes $A$ to $C$ (trachoma agent) was found in three women, but IgM was not present in their sera. 
TABLE Titres of antibodies against $C$ trachomatis serotypes $D$ to $K$ in sera from 154 prostitutes

\begin{tabular}{lllrrrrrr}
\hline \multicolumn{1}{c}{ Reciprocal antibody titres } \\
\cline { 2 - 8 } $\begin{array}{l}\text { Type of } \\
\text { antibody }\end{array}$ & 8 & 16 & 32 & 64 & 128 & 256 & $\begin{array}{l}\text { Total } \\
\text { positive }\end{array}$ \\
\hline IgG & NT & 13 & 22 & 44 & 35 & 31 & $\begin{array}{r}145(94) \\
\text { IgM }\end{array}$ \\
\hline
\end{tabular}

$\mathrm{NT}=$ not tested

Type-specific antibodies against $C$ trachomatis lymphogranuloma venereum (LGV) agents or Chlamydia psittaci agents were not detected.

Four cervical isolates were serotyped. These were identified as types $\mathrm{E}, \mathrm{F}, \mathrm{H}$, and $\mathrm{I}$.

\section{Discussion}

In the present study $94 \%$ of the prostitutes showed serological evidence of infection with $C$ trachomatis serotypes $\mathrm{D}$ to $\mathrm{K}$. In these women IgM antibody against these serotypes at a titre of $\geqslant 8$ indicating current infection was found in $29 \%$; $\mathbb{C}$ trachomatis was isolated from only $7 \%$ of women.

The rate of $34 \%$ of invalid cultures in this study is much higher than that of $6 \%$ reported in our laboratory using cervical specimens from women in London. ${ }^{7}$ This difference may be due to a higher rate of bacterial and fungal colonisation of the cervix in the prostitutes or because of large amounts of discharge collected in the specimens, which can cause cell toxicity.

The low chlamydial isolation rates reported here may have been due to the effects of storage and transportation of specimens, frequent treatment of the patients, or repeated reinfection of the cervix. In studies of trachoma in Iran, using the same methods of storage and transportation of clinical specimens, we obtained a very high isolation rate of $68 \%$ in children with trachoma. ${ }^{89}$ It is therefore probable that the method of storage and transportation had little or no effect on chlamydial isolation rates.

The women included in this study had been treated frequently, probably at sub-optimal levels, with drugs active against $C$ trachomatis. Studies of chlamydial ocular infection ${ }^{1011}$ have shown that systemic or topical treatment with antichlamydial drugs at suboptimal doses can reduce shedding of chlamydial agents and the intensity of the inflammatory responses.

In prostitutes repeated chlamydial infection of the cervix may be common. It has been shown that the chlamydial isolation rate in men who had had more than one episode of urethritis was one-quarter of the rate in those who were infected for the first time $(12 \%$ compared with $55 \cdot 6 \%$ ). ${ }^{12}$ Similar findings have been reported in guinea-pig chlamydial conjunctivitis used as a model for human ocular chlamydial infections. ${ }^{1314}$ It is therefore probable that lower isolation rates obtained in these women are partly caused by immune responses resulting from repeated chlamydial infections of the cervix.

High titres of type-specific $\operatorname{IgG}(\geqslant 256)$ were found in 31 of $145(21 \cdot 4 \%)$ seropositive women. These high titres of antibody may suggest that these women had an ascending chlamydial genital infection such as pelvic inflammatory disease (PID). Studies in our laboratory have shown that in women with noncomplicated cervical infection the serum IgG titres are usually between 64 and 128,6 whereas in those with PID or Curtis-Fitz-Hugh syndrome the IgG titre is considerably higher. ${ }^{15-17}$

The $C$ trachomatis serotypes $\mathrm{E}, \mathrm{F}, \mathrm{H}$, and I isolated in Teheran are commonly isolated from the genital tract of patients in Europe and the United States of America ${ }^{618}$ In this group of prostitutes, however, we found no evidence of genital infection caused by $C$ trachomatis serotypes A to C.

The results of this investigation indicate that in Iran prostitutes are commonly infected with $C$ trachomatis and are probably a major reservoir of chlamydial genital infection despite regular medical supervision.

The study was supported by grants from an anonymous donor and the Dulverton trust.

\section{References}

1. Darougar S, Jones BR, Cornell L, Treharne JD, Dwyer RStC. Aramesh B. Chlamydial urethral infection in Teheran; a study of male patients attending an STD clinic. $\mathrm{Br} J$ Vener Dis 1982; 58:374-6.

2. Gordon FB, Harper IA, Quan Al, Treharne JD, Dwyer RStC Garland JA. Detection of chlamydia (Bedsonia) in certain infections of man. I Laboratory procedures: comparison of yolk sac and cell culture for detection and isolation. J Infect Dis 1969;120:451-62.

3. Darougar S, Kinnison JR, Jones BR. Simplified irradiated McCoy cell culture for isolation of chlamydiae. In: Nichols RL, ed. Trachoma and Related Disorders Caused by Chlamydial Agents. Amsterdam: Excerpta Medica, 1971;64-70.

4. Treharne JD, Darougar S, Jones BR. Modification of the microimmunofluorescence test to provide a routine sero-diagnostic test for chlamydial infection. J Clin Pathol 1977;30:510-7.

5. Treharne JD, Katzenelson E, Davey SJ, Gray SJ. Comparison of serotyping sub-group A chlamydial isolates by a one-way crossreaction and by a two-way cross-reaction immunofluorescence test. In: Nichols RL, ed. Trachoma and Related Disorders. Amsterdam: Excerpta Medica, 1971;289-304.

6. Treharne JD, Dines RJ, Darougar S. Serological responses to chlamydial ocular and genital infections in the United Kingdom and Middle East. In: Hobson D, Holmes KK, eds. Nongonococcal Urethritis and Related Infections. Washington DC: American Society for Microbiology, 1977;249-58.

7. Burns DMcD, Darougar S, Thin RN, Lothian L, Jones BR, Nichols CS. Isolation of chlamydia from women attending the sexually transmitted disease clinic. BrJ Vener Dis 1975;51:314-8. 
8. Darougar S, Jones BR, Kinnison JR, Vaughan Jackson JD, Dunlop EMC. Chlamydial infections, advances in the diagnostic isolation of chlamydia including TRIC agent from the eye, genital tract, and rectum. Br J Vener Dis 1972;48:416-20.

9. Darougar S, Woodland RM, Forsey T, Cubbitt S, Allami J, Jones BR. Isolation of chlamydia from ocular infections. In: Hobson D, Holmes KK, eds. Non-gonococcal Urethritis and Related Oculogenital Infections. Washington DC: American Society for Microbiology 1977;295-8.

10. Jones BR. The prevention of blindness from trachoma. Trans Ophthalmol Soc UK 1975;95:16-33.

11. Darougar S, Jones BR, Viswalingam $\mathrm{N}$ et al. Family based suppressive intermittent therapy of hyperendemic trachoma with topical oxytetracycline or oral doxycycline. Br J Ophthalmol 1980;64:291-5.

12. Alani MD, Darougar S, Burns DMcD, Thin RN, Dunn $H$. Isolation of Chlamydia trachomatis from the male urethra. $\mathrm{Br}$ Vener Dis 1977; 53: 88-92.

13. Monnickendam MA, Darougar S, Treharne JD, Tilbury A. Guinea-pig inclusion conjunctivitis as a model for the study of trachoma; clinical, microbiological, serological and cytological studies of primary infection. Br J Ophthalmol 1980;64:279-83.
14. Monnickendam MA, Darougar S, Treharne JD, Tilbury A. The development of chronic conjunctivitis with scarring and pannus, resembling trachoma in guinea-pigs. $\mathrm{Br} J$ Ophthalmol 1980:64:284-90

15. Treharne JD, Ripa KT, Mårdh P-A Svennon L, Westrơm L, Darougar S. Antibodies to Chlamydia trachomatis in acute salpingitis. Br J Vener Dis 1979; 55:26-9.

16. Simmons PD, Forsey $\mathrm{T}$, Thin RN, et al. Antichlamydial antibodies in pelvic inflammatory disease. $B r J$ Vener $D i$ 1979;55:419-21.

17. Darougar S, Forsey T, Wood JJ, Bolton P, Allan A. Chlamydia and the Curtis-Fitz-Hugh syndrome. $B r J$ Vener Dis 1981;57:391-4

18. Wang S-P, Grayston JT, Kuo CC, Alexander ER, Holmes KK. Serodiagnosis of Chlamydia trachomatis infection with the micro-immunofluorescence test. In: Hobson D, Holmes KK, eds. Non-gonococcal Urethritis and Related Infections. Washington DC: American Society for Microbiology, $1977 ; 237-48$ 